\title{
AN EXAMINATION OF FLEXIBLE WORK ARRANGEMENTS, WORK-FAMILY CONFLICT, AND ORGANIZATIONAL OUTCOMES
}

\author{
Jacob Ongaki \\ Assistant Professor of Business Colorado Mesa University, USA \\ E-mail: jongaki@coloradomesa.edu
}

\begin{abstract}
The purpose of this quantitative study was to examine whether or not a relationship existed between employees' use of flexible working arrangements (such as flexible work schedules and telecommuting) and organizational outcomes (such as turnover intentions and job satisfaction outcome variables) holding work-family conflict and family-work conflict as covariate variables. The ANCOVA and Kruskal-Wallis technique was utilized in a survey data of 237 employees who utilized flexible work arrangements in the state of Texas. The ANCOVA and Kruskal-Wallis results revealed non-statistically significant results employees use flexible work options (such as flexible work schedules and telecommuting) to reduce work-family conflict and family-work conflict $(\mathrm{P}>0.05)$. The investigation found no statistical relations for the use of flexible work arrangements and outcome variables (such as work-family conflict, job performance, and turnover intentions). This issue would benefit researchers and organizational management together with human resources to recognize employees' challenges (work-family conflict and family-work conflict) and further investigate circumstances to reduce employees' negative feelings of job satisfaction and turnover intentions. Effective policies would likely improve and support employees' morale and boost organizational competitiveness in a global economy. Also, a study is needed to investigate employees' perceptions regarding the outcome variable if the flexible work arrangement options were reversed/rescinded in their organization.
\end{abstract}

Keywords: flexible work arrangements, telecommute, work-family conflict, job satisfaction, turnover intentions

$\underline{\text { ARTICLE INFO }}$

Article History:

Received: 21 March 2020

Accepted: 17 July 2020

Published: 31 December 2020 


\section{INTRODUCTION}

Work-family conflict has been a topic of much research since the 1970s, particularly in the field of organizational leadership (King, 2005). The workfamily conflict stems from the role of theoretical framework related to work and family interferences. The work and family roles often compete for fixed resources, thus, mutually incompatible that causes a role conflict (Grandey, Cordeiro, \& Crouter, 2005; Netemayer, Boles, \& McMurrian, 1996). The 2016 survey by the Society for Human Resource Management (SHRM) indicated that $46 \%$ of male and $43 \%$ of women professional workers experienced work-family conflict. The survey result was consistent with the 2008 survey by the National Study of Changing Workforce (Galinsky $\&$ Matos, 2011). Other polls (Nielsen and Harris along with Pew Research) reported that approximately 50 percent of working parents experienced work and family role interferences or difficulties (Parker \& Wang, 2013; ShannonMissal, 2014). The management support of flexible work arrangement declined from $31 \%$ to $14 \%$ between 2005 and 2016. Overall, the 2016 SHRM survey study concluded that about $35 \%$ of employees considered the autonomy of work-life-fit as one component of an effective workplace. Also, employees in an effective and flexible work experience higher job engagements, job satisfaction, intention to remain with their employers, and less work and family role conflict (Pandu, 2019). Workplace flexibility could help employees adjust working time as a resource to reduce pressure to fulfill multiple roles emanating from work and that of a family. The predicted exponential growth within the service sector (Coenen \& Kok, 2014; World Bank, n.d) has warranted this investigation. Employees' increased role demands and uncertain working schedules or unpredictable working hours such as early mornings, evenings, or weekends (Coenen \& Kok, 2014; Henly \& Lambert, 2014) present challenges (role conflict, turnover intentions, and job satisfaction) to the modern workforce. The issue of employees' role conflict between work and home domains has been observed in many decades (Greenhaus \& Boutell, 1985).

The modern era of global business competition could continue to exacerbate work-family conflict for many employees and organizations (De Janasz, Behson, Jonsen, \& Lankau, 2013; Odle-Dusseau, Hammer, Crain, \& Bodner, 2016). This necessitated the investigation of the effects of employees' use of flexible work arrangements such as a flexible work 
schedule and telecommute, work-family conflict, family-work conflict, and organizational outcomes such as turnover intentions and job satisfaction. The 2016 survey by SHRM suggested that many businesses experienced an $18 \%$ turnover rate. About $77 \%$ of organizations would retain their best workers and $39 \%$ of those firms offer flexible work arrangement options for retention purposes. The workforce demographics of the United States (US) has changed over the last few decades as a result of a growing number of female workers, dual-earner families, single parents, divorced workers, and members of the Generations X and Y (Jerome, Scales, Whithem, \& Quain, 2014; Minnotte, 2012). Many of these workers could be faced with role involvement and conflicts related to work and family demands. The changes to family structures and demographics since the mid-1980s have increased employees' responsibilities of work and family in many industries in the United States (Galea, Houkes, \& De Rijk, 2014).

The role demand and limited resources often lead to resource constrain with an organization and indirectly affect employees' work performance (Cheung \& Wong, 2013). Modern workers will face challenges of managing multiple responsibilities including work and personal roles (Bryan, 2012). In 2012, Society for Human Resource Management report ranked workplace flexibility benefits of organizations as the highest in priority besides job compensation and career opportunities for job seekers (Cairns, 2013). The Fortune magazine reported that $82 \%$ of the best 100 companies offered employees the option to work at least $20 \%$ of the time remotely. The concept of schedule flexibility remains a voluntary option for many employers (Cairns, 2013). Flexible work schedules and telecommuting programs have been the most favored forms of flexible work arrangement practices in many organizations nationwide (Wells-Lepley, Thelen, \& Swanberg, 2015). The options are offered to mitigate employees' work-family or inter-role conflicts (Allen, Johnson, Kiburz, \& Shockley, 2013). These programs have been found negatively related to work-family conflict (De Sivatte \& Guadamillas, 2013; Duncan \& Pettigrew, 2012; Thompson, Beauvais, \& Lyness, 1999). The inter-role conflict may harm organizational outcomes such as turnover and job satisfaction (Pandu, 2019). Reduced levels of work-family conflict may improve job satisfaction and worker productivity (Blazovich, Smith, \& Smith, 2013; Carlson, Hunter, Ferguson, \& Whitten, 2014). This fosters organizational competitiveness, sustainable growth, and profitability in a global economy (Fiksenbaum, 2013; Maharshi \& Chaturvedi, 2015). The 
increased work-family conflict and advancement in information technology necessitated the investigation of the differences of employees' use of flexible work arrangements (such as a flexible work schedule and telecommute), work-family conflict, family-work conflict, and organizational outcomes (such as turnover intentions and job satisfaction). The next section entails the literature review of this study.

\section{LITERATURE REVIEW}

Work and family are the two most important spheres in an individual's life (Mortimer, Lorence, \& Kumka, 1986). The pressures and stressors at work take time away from the family, resulting in the incompatibility of work and family concerns (King, 2005). The conflict is supported by the role theoretical frameworks (Katz \& Kahn, 1978; Goode, 1960; Weiner, 1974; Weiner et al., 1971). The theory suggests that work and family interface force an employee to perform conflicting multiple roles between the two domains and contributes to a negative appraisal (DiRenzo, Greenhaus, \& Weer, 2011; Greenhaus \& Beutell, 1985; Greenhaus \& Powell, 2006; Kossek \& Ozeki, 1998; Lazarus, 1991; Poposki, 2011). The work roles involve employee's duties and responsibilities in addition to home-related responsibilities such as a caretaker (children and the elderly) and family activities and obligations. Individuals often attribute the conflict experienced to external factors such as work and family resource demand requirements to complete multiple roles (Katz \& Kahn, 1978; Zhang, Griffeth, \& Fried, 2012). Modern fulltime employees are expected to work long hours (Munsch, Ridgeway, \& Williams, 2014) and have been unwilling to sacrifice personal values for good pay and their jobs (Chernyak-Hai \& Tziner, 2015). Despite a high acceptance level of flexible work arrangement practices among workers, the programs are out of reach in many organizations (SHRM 2016; Sweet, Pitt-Catsouphes, Besen, \& Golden, 2014). Flexible work scheduling has become a more prevalent and most cherished benefit among workers. Flexible work options provide leverages to manage work and life roles more effectively (Zito et al., 2019). A quantitative investigation which included 389 respondents in a public agency based on the structural equation model and demand resource model found a negative relationship between job satisfaction and work-family conflict (Zito et al., 2019). It has also been studied that informal flexible working arrangements provide employees 
the opportunities to manage their work better (such as options to perform certain duties later, discretion on work start or end times, or work remotely) without compromising work performance (Rhee, Park, \& Lee, 2019; Zito et al., 2019).

Employees' family and work roles have become intertwined and often result in demand conflict (Sturman \& Walsh, 2014). Sturman and Walsh (2014) examined the relationships of employees' working hours with fit and organizational support, job stress, work-family conflict, and turnover intentions. The results revealed that the majority of workers worked 13 extra hours per week (Sturman \& Walsh, 2014). Organizational support and employers attentive to respond to workers' needs may induce positive behaviors, feelings, and attitudes likely boost morale on the aspect of the job (Locke, 1976). This could result in a long-lasting relationship for employees and the organization (Sturman \& Walsh, 2014) and reduced negative organizational outcomes (such as decreased turnover intentions and increased job performance). Long-working hours may result in a work-hours misfit, which negatively affects employees' attitudes towards work and the organization. An employee may feel less satisfied with personal and work roles because of role demands (Sturman \& Walsh, 2014). The feelings of increased role-conflicts result in intentions to leave the organization.

Employees are more fulfilled and satisfied with work and family roles when full concentration is reached. The work-family conflict is felt when one or both spheres are not completed effectively. A psychological state of mind and conscientiousness. Lack of focus, receptive to attention, and self-awareness (emotions, thoughts, and feelings) because of role conflict may result in a deficiency in full concentration and hampers outcome such as decreased job satisfaction and intention to quit their current job (Raza et al., 2018). Based on a study that utilized both qualitative (focus study group) and quantitative (field data analysis) investigation methods, workfamily conflict issues correlated negatively towards work attitudes. The sample population included 48 graduate students from a public university of Naples in Southern Italy who engaged in a roundtable discussion. The lack of organizational mechanisms to assist workers to manage work and personal life may lead to lower morale and result in consequences such as decreased employees' job satisfaction (Buonocore, Russo, \& Ferrara, 2015; Zito et al., 2019). A recent study revealed that the use of flexible work 
arrangements alleviated work-family conflict increased job satisfaction (Chen, Brown, Bowers, \& Chang, 2015), and decreased turnover intentions (Tripathi \& Pandey, 2017).

The use of flexible work arrangements may be successful when explicitly stated in the company policy and supported by managers (Gözükara \& Çolakoğlu, 2015). Flextime and telecommuting (increased to $66 \%$ in 2016 compared $34 \%$ in 2005 and has remained steady within the last four years) are the most favored forms of flexible work arrangement practices and supported by about $58 \%$ of supervisors in many organizations nationwide (Wells-Lepley et al., 2015). Telecommuting trended up 34\% and $66 \%$ in 2005 and 2016 with small companies than large companies likely to offer workplace flexibility (SHRM, 2016). The survey of the Society for Human Resource Management or SHRM (2013), work-life accommodation practices such as flexible work arrangements have been the most popular benefit for many new hires. The survey included private and public faculty members in Punjab, Pakistan who indicated a positive association between flexible work arrangement practices and standard benefits and job satisfaction (Galea et al., 2014). Conversely, Bhave, Kramer, and Glomb (2013) found a negative relationship between employees' satisfaction with organizational benefits (such as medical health insurance and pay) and work-family conflict. The conflicting results and increased employees' demand for flexible work arrangements (Burke, Koyuncu, \& Fiksenbaum, 2013; Wells-Lepley et al., 2015) necessitates this study.

Flexible work arrangement practices are believed to help employees manage work and personal roles and in turn, lead to job satisfaction and boost firm goals (Wells-Lepley et al., 2015). A qualitative case study investigation by Atkinson and Hall (2011) about the effects of flexible work arrangements revealed that employees were satisfied with the practices that increased their wellbeing. Another study by De Sivatte and Guadamillas (2013) explored the impact of employees' use and implementation of flexible work arrangements on organizational outcomes. The survey included 480 responses from many private organizations in Spain where flexible work arrangement practices were available. These results were similar to Goh, Ilies, and Wilson (2015) and Gözükara and Çolakoğlu (2015). It was concluded that informal rather than formal practices were more effective in reducing work-family conflict (Goh et al., 2015). We followed the same line of investigation to examine 
whether workplace flexibility helped to create extra resources needed to reduce employees' multiple role conflicts. Indeed, an employee who does not have full concentration at work because of multiple role demands may have negative consequences (feelings of intentions to leave and reduced job satisfaction). The later would likely affect organizational outcomes indirectly related to new employee training associated costs.

The work-family conflict has gotten public and national attention due to its prevalence. For example, the CEO of Pepsi-Cola in North America left her job due to conflicting schedules and an inability to navigate between work and life demands (Brown, 2010). Also, Anne-Marie Slaughter publically left a high senior level position in the state department due to work-family conflict (Burke et al., 2013). A relationship between flexible work arrangements and turnover intentions has not been confirmed (Ahmad, Shaw, Bown, Gardiner, \& Omar, 2016). Ahmad et al. (2016) found mixed results or no significant relationship between flexible work arrangements and turnover intentions. The study included 382 Malaysian workers to determine the mediating effect of flexible work arrangements and intention to leave their organization. Also, De Sivatte and Guadamillas (2013) found no evidence related to flexible work arrangement use and turnover intentions. A more recent study also found no correlation between work-family conflict and employees' intentions to leave their current jobs (Burke et al., 2013). The recent study by Pandu (2019) concluded that work-family conflict influence employees' job satisfaction (0.99) and turnover intentions (0.81) model weight results. The sample size included 173 of IT workers and teachers in the Channel based on the structural equation model. However, an earlier study by Buonocore and Russo (2013) suggests that work and family roles are expected roles and any conflict is absorbed and mitigated by resource allocation. This may not be the case because of increased multiple roles and fixed resources. The role demand and strained resources result in increased work-family conflict. The issue of role conflict among employees is present in many studies. The conflict could lead to employee's negative feelings of decreased job satisfaction and intention to leave their job. We hypothesize and fill the gap in prior studies that the use of flexible work arrangements may help buffer the multiple role strain by better utilization of resources (such as flexible work schedule and telecommuting) options (Buonocore \& Russo, 2013). Increased work-family conflict and advancement in information technology necessitated the investigation of the differences 
of employees' use of flexible work arrangements (such as a flexible work schedule and telecommute), work-family conflict, family-work conflict, and organizational outcomes (such as turnover intentions and job satisfaction). Because of the overwhelming role demands and interference, the use of flexible work arrangement options could mitigate the work-family conflict and benefit work and family domains. The question is whether flexible work arrangement programs could mitigate work-family conflict and lead to reduced employee turnover and increased job satisfaction that has farreaching negative consequences among employees and their organization.

\section{METHODOLOGY}

The quantitative design was used to investigate work-family conflict as a real issue in operations and management and to test role theoretical knowledge by minimizing subjectivity and maximizing objective study analysis (Grandey et al., 2005; Wahyuni, 2012). The variables and constructs for the study included the flexible working arrangements (flextime and telecommuting practices) as predictor variables, work-family conflict and family-work conflict as covariates, and job satisfaction and turnover intentions as outcome variables. The demographic composition of whitecollar employees' in the study included age, gender, education, income, rank, race, and job classification or tenure. The demographic information would be valuable to further their relations with core variables for the study. The Web survey (via Qualtrics software), an online self-administered questionnaire was the primary method of data collection. The survey participants were primarily recruited through organizations and the researcher's networks. The snowballing technique was used as a secondary or complementary recruitment technique. The identified sample was requested to forward the email/text message request and the link to potential participants through their social networks (snowballing). The ANCOVA and Kruskal-Wallis research techniques were used given the nature of the s complexity and assumptions in the survey data.

A survey was sent to 360 employees in primarily two institutions in Dallas/Fort Worth and Arlington Texas. Purposive sampling surveys ensured geographical and employees with flexible work arrangements experience restrictions. A minimum sample size estimate was reached based 
on the $\mathrm{G}^{*}$ Power analysis and a $95 \%$ confidence interval or alpha of 0.05 for a two-tailed test. The response rate was about $50 \%$ which accounted for 360 initially sent invitations, 72 invitations sent via snowballing, and 40 distributed through business cards. The sample size for the included 237 workers with formal and/or informal flexible work arrangement practices, such as flexible schedules and telecommuting options. A total of 21 responses were not usable due to incomplete critical data or failure to respond to indicate the type of flexible work arrangements utilized.

The questionnaire survey enabled the researcher to collect raw data on flexible work arrangements about workers' beliefs, attitudes, and emotions concerning outcome variables. The 25 survey questions were structured, specific, and narrowed to minimize general phenomenon by assigning measurable values related to specific constructs and scales. Each question was linked directly to a specific construct and instrument scale to analyze the variables' association strengths. The ANCOVA and Kruskal-Wallis data assumption were analyzed to assess participants' perceptions. The survey questions were chosen from various previously published instruments to measure employees' perceptions and feelings about the study variables. The instruments used to create the survey questions included flexible work arrangement practices (Thompson et al., 1999; Swanberg, McKechnie, Ojha, \& James, 2011), work-family conflict (Matthews, Kath, \& BarnesFarrell, 2010), job satisfaction (Yang, Mossholder, \& Peng, 2009), and turnover intentions (Kirchmeyer \& Bullins, 1997). The flexible work arrangement types categorical measures or dummy variables were coded as 1 , telecommuting as 2 , and 3 for both preferences within the last five years (Thompson et al., 1999) Likert-type scale.

The work-family conflict and family-work conflict instrument were used to assess employees' inter-role conflict as a result of fixed resources related to demands, time constraints, and strain associated with work and personal responsibilities. The sum score questions were averaged to produce a constructed measure based on Matthews et al.'s (2010) Likert-type scale. The job satisfaction measure was based on structural equation modeling involving cognitive behavior with work and job satisfaction in organizational leadership which had been tested with a coefficient alpha of .83 (Yang et al., 2009). The original turnover intentions instrument measured cognitive and behavioral components of intentions and behaviors of searching for new jobs 
and included a Cronbach's alpha of .67 (Kirchmeyer \& Bullin, 1997). The sum score for each instrument was averaged to produce a variable measure of a Likert-type scale. The study variables were interval variables within the survey measured through Likert-type interval scales (Table 1). For each construct item, the lowest score meant less agreement to the statement and the highest score translated to complete agreement with the statement. The questionnaire items were tabulated to reflect the participants' responses and to evaluate the variable relationships regarding the use of flexible work arrangements and work-family conflict on organizational outcomes.

Table 1: Summary of Variable Operationalization

\begin{tabular}{|c|c|c|c|c|}
\hline Variable & Original Source & $\begin{array}{l}\text { Scaling } \\
\text { Method }\end{array}$ & $\begin{array}{l}\text { Points } \\
\text { Scale }\end{array}$ & Likert-type Scale \\
\hline $\begin{array}{l}\text { Flexible-work } \\
\text { arrangements }\end{array}$ & $\begin{array}{l}\text { Thompson et al. } \\
\text { (1999) }\end{array}$ & Nominal & 3-Point & $\begin{array}{l}\text { Flextime (1) Telecommuting } \\
\text { (2) Both (3) }\end{array}$ \\
\hline Work-family conflict & $\begin{array}{l}\text { Matthews et al. } \\
\quad(2010)\end{array}$ & Interval & 5-Point & $\begin{array}{l}\text { Strongly disagree (1) to } \\
\text { Strongly agree (5) }\end{array}$ \\
\hline Family-Work conflict & $\begin{array}{l}\text { Matthews et al. } \\
\quad(2010)\end{array}$ & Interval & 5-Point & $\begin{array}{l}\text { Strongly disagree (1) } \\
\text { Strongly agree (5) }\end{array}$ \\
\hline Job satisfaction & $\begin{array}{l}\text { Yang et al. } \\
\text { (2009) }\end{array}$ & Interval & 7-Point & $\begin{array}{l}\text { Strongly disagree (1) to } \\
\text { Strongly agree (5) }\end{array}$ \\
\hline Turnover intentions & $\begin{array}{c}\text { Kirchmeyer \& } \\
\text { Bullin (1997) }\end{array}$ & Interval & 7-Point & $\begin{array}{l}\text { Strongly disagree (1) } \\
\text { Strongly agree (7) }\end{array}$ \\
\hline
\end{tabular}

Source: Own

\section{Data Analysis}

The Qualtrics web-based software enabled the extraction of data in a SPV format uploaded in SPPS for data analyses. The core survey questions were linked to a respective construct for analyzing variable relationships. Each subcategory was summed based on an interval scale instrument. The SPSS utilized to compute ANCOVA and Kruskal-Wallis coefficients to determine the relationships for the predictor and outcome variables while considering the covariate variables. The statistical descriptive outputs (such as mean, median, mode, standard deviation data, and central tendency) were assessed to determine demographic composition. The ANCOVA and Kruskal-Wallis assumptions were visually and graphically inspected (such as histograms and probability, Q-Q, and scatter plots) to study pattern and trend relationships. The validity was evaluated based on specific instruments and compared to previously published studies. The ANCOVA and KruskalWallis assumptions such as normal data or symmetric distributions were 
evaluated based on the dependent variable dataset. The study covariates were analyzed against the dependent variables. The results showed a fairly linear relationship within each level of the independent variable. The variance homogeneity produced a mixed result within each level of the independent variable. The Kolmogorov-Smirnov and Shapiro-Wilks normality tests were significant $(\mathrm{P}<.05)$ suggesting that data was not normally distributed based on ANCOVA validation assumptions (independent variables vs dependent variables) except for the relationship of family work-conflict outcome and telecommuting variable indicated non-significant result $\mathrm{P}>.05$ that data was normally distributed (Table 2). The ANCOVA assumptions require a linear relationship between the dependent variables and covariate variables within each level of the independent variable, continuous data, variance homogeneity, and normally distributed data within each level of the independent variable. Because of inconclusive data to meet normality assumptions, the Kruskal-Wallis technique was explored for the nonparametric dataset.

Table 2: Normality

\begin{tabular}{|c|c|c|c|c|c|c|c|}
\hline \multirow{2}{*}{$\begin{array}{l}\text { Dependent } \\
\text { variables }\end{array}$} & \multirow{2}{*}{$\begin{array}{l}\text { Flexible work } \\
\text { arrangements }\end{array}$} & \multicolumn{3}{|c|}{$\begin{array}{l}\text { Kolmogorov- } \\
\text { Smirnov }\end{array}$} & \multicolumn{3}{|c|}{ Shapiro-Wilk } \\
\hline & & Statistic & df & Sig. & Statistic & df & Sig. \\
\hline \multirow{3}{*}{$\begin{array}{l}\text { Work-family } \\
\text { conflict }\end{array}$} & Flexible schedule & .11 & 97 & .00 & .96 & 97 & .01 \\
\hline & Telecommuting & .14 & 37 & .08 & .95 & 37 & .12 \\
\hline & $\begin{array}{l}\text { Flexible schedule } \\
\& \text { Telecommuting }\end{array}$ & .10 & 103 & .01 & .97 & 103 & .01 \\
\hline \multirow{3}{*}{$\begin{array}{l}\text { Family-work } \\
\text { conflict }\end{array}$} & Flexible schedule & .16 & 97 & .00 & .95 & 97 & .00 \\
\hline & Telecommuting & .21 & 37 & .00 & .91 & 37 & .00 \\
\hline & $\begin{array}{l}\text { Flexible schedule } \\
\text { \& Telecommuting }\end{array}$ & .16 & 103 & .00 & .95 & 103 & .00 \\
\hline \multirow{3}{*}{$\begin{array}{l}\text { Job } \\
\text { satisfaction }\end{array}$} & Flexible schedule & .24 & 97 & .00 & .89 & 97 & .00 \\
\hline & Telecommuting & .32 & 37 & .00 & .79 & 37 & .00 \\
\hline & $\begin{array}{l}\text { Flexible schedule } \\
\text { \& Telecommuting }\end{array}$ & .30 & 103 & .00 & .84 & 103 & .00 \\
\hline
\end{tabular}




\begin{tabular}{llccccccc}
\hline $\begin{array}{l}\text { Dependent } \\
\text { variables }\end{array}$ & $\begin{array}{l}\text { Flexible work } \\
\text { arrangements }\end{array}$ & \multicolumn{3}{c}{$\begin{array}{c}\text { Kolmogorov- } \\
\text { Smirnov }\end{array}$} & \multicolumn{3}{c}{ Shapiro-Wilk } \\
& Statistic & df & Sig. & Statistic & df & Sig. \\
\hline Turnover & Flexible schedule & .13 & 97 & .00 & .91 & 97 & .00 \\
intentions & Telecommuting & .13 & 37 & .13 & .94 & 37 & .04 \\
& $\begin{array}{l}\text { Flexible schedule } \\
\text { \& Telecommuting }\end{array}$ & .12 & 103 & .00 & .92 & 103 & .00 \\
& & & & & & \\
\hline
\end{tabular}

Source: Own

The make-up of employees' use of flexible work schedules represented 97 (40.9\%), 37 (15.6\%) comprised of telecommuters or remote workers, and approximately $103(43.5 \%)$ utilized both flexible work schedules and telecommuting in their organization. The survey respondents were 133 males and 104 females and 138 married employees with children under 18 years old. Employees included 111 with a bachelor's degree and 84 with a master's degree and higher. About $45 \%$ of employees had worked in the firm for more than 3 years. About $60.3 \%$ included individuals with two or more income earners within the family.

Variable data transformations were performed to normalize data to fit parametric analysis. The methods of data transformation included the logarithm method for a family-family conflict and turnover intention dataset and the logarithm exponential for job satisfaction data (Greene, 2012). Data transformation helped to reduce skewness and kurtosis to less than 1. Because data normality was inconclusive, the researcher further performed Kruskal-Wallis test analysis (which does not require normally distributed data) to confirm the rigorous nature of the study. Descriptive analyses such as measures of central tendency were examined before testing the study variables. The range scores (minimum and maximum), mean, standard deviation, skewness, and kurtosis were examined for the dependent variables of work-family conflict, family-work conflict, job satisfaction, and turnover intentions as shown in Table 3. 
Table 3: Descriptive Analysis (Untransformed)

\begin{tabular}{lcccc}
\multicolumn{1}{c}{ Category } & $\begin{array}{c}\text { Work-family } \\
\text { conflict }\end{array}$ & $\begin{array}{c}\text { Family-work } \\
\text { conflict }\end{array}$ & $\begin{array}{c}\text { Job } \\
\text { satisfaction }\end{array}$ & $\begin{array}{c}\text { Turnover } \\
\text { intentions }\end{array}$ \\
\hline Mean & 2.85 & 2.3 & 3.93 & 3.16 \\
Std. Deviation & 0.1 & 0.86 & .84 & 1.69 \\
Skewness & 0.3 & 0.58 & -1.04 & .49 \\
Std. Error of & 0.16 & 0.16 & .16 & .16 \\
Skewness & -0.38 & 0.19 & 1.47 & -.70 \\
Kurtosis & 0.32 & 0.32 & .32 & .32 \\
Std. Error of Kurtosis & & & &
\end{tabular}

The outliers were within \pm 3 in the data range and there were no extreme outliers outside the mean range and standard deviation. Therefore, there were no cases with standardized residuals. The skewness and kurtosis were valid and robust measures for normally distributed data (Field, 2013). The skewness or the kurtosis values were less than one for the dependent variables which were an indication of a fairly distributed data for parametric analysis. Therefore, the visual inspection, skewness, and kurtosis suggested that the study data met the minimum data distribution requirement. The Levene's test was not statistically significant meeting homogeneity or equal variances for dependent variables, $P>.05$ (see Table 4 ) at each level. The interaction between flexible work arrangements and covariates work-family conflict and family-work conflict (test of between-subjects effects) were not statistically significant meeting ANCOVA homogeneity assumption $(\mathrm{P}>.05)$ as shown in Table 5. The Durbin-Watson test was 1.87 which confirmed no autocorrelation of residuals among predictor and outcome variables (Greene, 2012). The values were within the acceptable range of critical values.

Table 4: Levene's tests

\begin{tabular}{lcc}
\hline \multicolumn{1}{c}{ Covariate } & Job satisfaction & Turnover intentions \\
\hline Work-family conflict & 0.72 & 0.13 \\
Family-work conflict & 0.68 & 0.69 \\
\hline Source: Own & &
\end{tabular}


Table 5: Homogeneity

\begin{tabular}{lcc}
$\begin{array}{c}\text { Dependent } \\
\text { variable }\end{array}$ & $\begin{array}{c}\text { Flexible work } \\
\text { arrangement*work- } \\
\text { family conflict (Sig.) }\end{array}$ & $\begin{array}{c}\text { Flexible work } \\
\text { arrangement*family- } \\
\text { conflict (Sig.) }\end{array}$ \\
\hline Job satisfaction & 0.38 & 0.68 \\
Turnover intentions & 0.48 & 0.95 \\
\hline
\end{tabular}

Source: Own

The parametric assumption violation of normality created doubt or authenticity of the ANCOVA findings or the study was not considered rigorous enough. This warranted further analysis to perform KruskalWallis analysis for non-parametric data analysis with less restriction on data normality assumption as an alternative to avoid study ambiguity. The Kruskal-Wallis was employed after several data transformations (such as $\log$ transformations, square roots, and inverse or reciprocal methods) failed to produce consistent results or due to non-significance coefficients data assumption of normality test of normally distributed data according to the Kolmogorov-Smirnov and the Shapiro-Wilks normality tests. The KruskalWallis analysis was done to determine if there were any differences between employees' use of flexible work arrangement types (flexible work schedule and telecommuting) and in the means of employees' work-family conflict, family-work conflict, and the organizational outcomes of job satisfaction and turnover intentions. The data was measured on Likert scales for dependent variables, with three levels of flexible work arrangements coded as dummy variables (flexible work schedule, telecommuting, and utilization of both options) based on Kruskal-Wall analyses (Field, 2013). The SPSS labels the Kruskal-Wallis test as chi-square $\left(\mathrm{X}^{2}\right)$ measurement and uses "Asympt. Sig." as to whether significant or not significant (Field, 2013). The Kruskal-Wallis results indicated no significant differences between predictors (flexible work arrangements) and the outcome variables which was consistent with the ANCOVA result (Table $6 \& 7$ ). Further evaluation of effect size based on the chi-square result was not necessary. 
Table 6: Tests Between Subjects (Covariates)

\begin{tabular}{lcc} 
Dependent variable & $\begin{array}{c}\text { Work-family conflict } \\
\text { (covariate Sig.) }\end{array}$ & $\begin{array}{c}\text { Family-work conflict } \\
\text { (covariate Sig.) }\end{array}$ \\
\hline Job satisfaction & 0.68 & 0.80 \\
Turnover intentions & 0.69 & 0.36 \\
\hline
\end{tabular}

Source: Own

Table 7: Kruskal-Wallis H Outcome Variable Statistic Tests

\begin{tabular}{lcccc}
\hline Category & $\begin{array}{c}\text { Work-family } \\
\text { conflict }\end{array}$ & $\begin{array}{c}\text { Family-work } \\
\text { conflict }\end{array}$ & $\begin{array}{c}\text { Job } \\
\text { satisfaction }\end{array}$ & $\begin{array}{c}\text { Turnover } \\
\text { intentions }\end{array}$ \\
\hline Chi-square & 1.56 & 5.74 & 0.59 & 3.18 \\
Asymp. Sig. & 0.46 & 0.06 & 0.75 & 0.20 \\
\hline Source: Own & & & &
\end{tabular}

\section{RESULTS AND DISCUSSION}

The ANCOVA parametric analysis results indicated no significant relationships between flexible work arrangement types (flexible work schedules and telecommuting) independent variables and dependent variables (turnover intentions and job satisfaction) or $\mathrm{P}>.05$ (Table 6) considering covariate variables (work-family conflict, family-work conflict). The Kruskal-Wallis non-parametric and ANCOVA technique for parametric data analysis produced similar results that had no statistically significant differences between employees' use of flexible work arrangement types (flexible work schedules and telecommuting) independent variables and dependent variables (work-family conflict, family-work conflict, turnover intentions, and job satisfaction) or $\mathrm{P}>.05$ (Table $6 \& 7$ ). The result was inconsistent with a recent study that concluded that employees' job autonomy and job crafting may create resources from task prioritization to buffer against work-family conflict (Zito et al., 2019). The lack of support of work-family conflict concerning job satisfaction and turnover may be that employees are less likely to blame work interference with family because such interference is expected (Grandey et al., 2005). Also, the availability of technology enables multitasking and efficient resource utilization without causing much role conflict. Employees may anticipate role conflict and the two domains co-exist as a balancing act that diffuses negative feelings toward work roles. Buonocore and Russo (2013) explained that work and 
family roles share common features and characteristics behaviors that complement and useful to employees.

Because there were no statistically significant relationship/differences (for ANCOVA and Kruskal-Wallis results), the post hoc/pairwise comparison tests were not necessary. The post hoc result would have revealed the flexible work arrangement group/s if there was a statistically significant difference. The conclusion of the study indicated no statistically significant differences between employees' use of flexible work arrangement types (flexible work schedule and telecommuting) and the means of employees' work-family conflict ( $\mathrm{P}>.05)$, family-work conflict $(\mathrm{P}>.05)$ employees' job satisfaction $(\mathrm{P}>.05)$, and turnover intentions $(\mathrm{P}>.05)$ as shown in Tables 6 and 7 . The result is contrary to recent findings that work-family conflict translates to employees' turnover intentions ( $\mathrm{Li}, \mathrm{Li}$, Wang, \& Newton, 2019). However, the study is consistent with Pavalko and Henderson (2006) and Neal and Hammer (2007) who found no relationship between conflict and the availability of flexible options. The study investigated the influence of work-family conflict and turnover intentions of 175 employees within the construction industry in China that unmanaged family roles could affect bad feelings about the job and intention to leave the company. The Li et al., (2019) was supported by a longitudinal study that examined the antecedents of work-family balance and turnover intentions (Moazami-Goodarzi, Nurmi, Mauno, Aunola, \& Rantanen, 2019).

The results of ANCOVA and the Kruskal Wallis for white-collar employees studied in this research does not confirm that organizational available resources such as employees' control of their schedule and telecommuting help to alleviate the inter-role conflict between work and family. Because of the non- statistically significant effect, the findings of the study may imply a blurred relationship between work and family roles. About $51 \%$ of employees could be working long hours transferring non-work roles to family. This suggests that it is difficult for employees to differentiate between work and family roles (SHRH, 2016). The respondents in this study have often utilized flexible work arrangements as a normal business practice and may not feel the difference until the options are limited or reversed. This was consistent with prior research as expected and many employees may be used to multiple roles (Buonocore \& Russo, 2013). We argue that the regular use of technology and modern family values may explain the 
study outcome that many employees already utilize flexible work options. For example, 24/7 communication among employees and their managers through the use of available technology that balances work and family roles and mitigates/decreases work-family conflict (Harris, Harris, Carlson, \& Carlson, 2015). The result could be a result of an employee's economic and social support (such as from friends and family). The work-family conflict may not be felt (Somech \& Drach-Zahavy, 2012). This explains the inconsistencies within the literature. This could be an avenue for further studies Future research should replicate this study to include flexible work arrangement users vs. non-flexible work arrangement employees. Also, extending this research beyond the service sector and region studied would be worthwhile. A study is needed to investigate employees' perceptions regarding the outcome variable if the flexible work arrangement options were reversed in their organizations. Lastly, a longitudinal study incorporating many variables would be beneficial to determine causation because modern workers are likely to face an inter-role conflict between work and that of a family. Given the fact that many employees have been working from home due to the Coronavirus pandemic, it would be interesting to know if this would change employee's perception of flexible work arrangements. Also, further investigation could shed light on whether an employee's performance increases during the pandemic period for those who worked from home and experienced less work-family conflict.

\section{CONCLUSION}

The research results do not confirm that organizational available FWAs resources such as employees' control of their schedule and telecommuting help to alleviate the inter-role conflict between work and family. The workfamily role interference is real and our findings suggest a need for continued research on FWAs affect WFC and FWC, especially on organizational outcomes. Because of the non- statistically significant effect, the findings of the study may imply a blurred relationship between work and family roles. This suggests that organizational leaders must review available flexible work arrangements programs that suits and satisfies the majority of employees' needs and that of the firm. About $51 \%$ of employees could be working long hours transferring non-work roles to family. This suggests a difficulty for employees to differentiate between work and family roles 
(SHRH, 2016). Organizations must develop work-family cultures and policies for the development and implementation of work-family programs that accommodate employees' obligation flexibility. The respondents in this study have often utilized flexible work arrangements as a normal business practice and indifference to separate work and family roles. Future research should replicate this study to include flexible work arrangement users vs. non-flexible work arrangement employees. Also, extending this research beyond the service sector and region studied would be worthwhile. A study is needed to investigate employees' perceptions regarding the outcome variable if the flexible work arrangement options were reversed in their organizations. Lastly, a longitudinal study incorporating many variables would be beneficial to determine causation because modern workers are likely to face an inter-role conflict between work and that of a family. The lack of evidence stirs further investigation to examine whether flexible work arrangements programs are beneficial to employees and their organization. Work-family conflict is a critical problem for organizations and individuals and is a win-win situation that requires employers' attention, particularly to improve job satisfaction and turnover intentions. Multiple conflicting roles drains an employee's physical and psychological wellbeing and a predictor of work withdrawal as supported by the Role Theory.

\section{ACKNOWLEDGEMENTS}

Jacob M. Ongaki is an assistant professor in Business at Colorado Mesa University, Colorado (USA). Obtained Ph.D. in Business (Finance) from Northcentral University Arizona, USA. Before the current position, Dr. Ongaki worked in a corporate capacity for more than a decade (where he developed motivation and interest in management) and taught as an adjunct professor in various institutions within the United States. Future research interest would include finance (corporate and investment) and organizational management related issues.

\section{REFERENCES}

Ahmad, A., Shaw, N. E., Bown, N. J., Gardiner, J., \& Omar, K. (2016). The impact of negative work home interface on intention to leave and 
the role of flexible working arrangements in Malaysia. The Journal of Developing Areas, 50(5), 507-515.

Allen, T. D., Johnson, R. C., Kiburz, K. M., \& Shockley, K. M. (2013). Work-family conflict and flexible work arrangements: Deconstructing flexibility. Personnel Psychology, 66, 345-376.

Atkinson, C., \& Hall, L. (2011). Flexible working and happiness in the NHS. Employee Relations, 33, 88-105.

Bhave, D., Kramer, A., \& Glomb, T. (2013). Pay satisfaction and workfamily conflict across time. Journal of Organizational Behavior, 34, 698-713.

Blazovich, J. L., Smith, K. T., \& Smith, M. (2013). Employee-friendly companies and work-life balance: Is there an impact on financial performance and risk level? Journal of Organizational Culture, Communications, and Conflict, 18(2), 1-13.

Brown, L. M. (2010). The relationship between motherhood and professional advancement. Employee Relations, 32, 470-494.

Bryan, M. L. (2012). Access to flexible working and informal care. Scottish Journal of Political Economy, 59, 361-389.

Buonocore, F., \& Russo, M. (2013). Reducing the effects of work-family conflict on job satisfaction: The kind of commitment matters. Human Resource Management Journal, 23(1), 91-108.

Buonocore, F., Russo, M., \& Ferrara, M. (2015). Work-family conflict and job insecurity: Are workers from different generations experiencing true differences? Community, Work \& Family, 18, 299-316.

Burke, R. J., Koyuncu, M., \& Fiksenbaum, L. (2013). Antecedents and consequences of work-family conflict and family-work conflict among frontline employees in Turkish hotels. IUP Journal of Management Research, 12(4), 39-55. 
Cairns, T. D. (2013). What will tip the scales for flexible work arrangementsmotivation or collaboration? Employment Relations Today (Wiley), 40(2), 29-33.

Carlson, D., Hunter, E., Ferguson, M., \& Whitten, D. (2014). Work-family enrichment and satisfaction: Mediating processes and relative impact of originating and receiving domains. Journal of Management, 40(3), 845-865.

Chen, I. H., Brown, R., Bowers, B. J., \& Chang, W. Y. (2015). Work-tofamily conflict as a mediator of the relationship between job satisfaction and turnover intention. Journal of Advanced Nursing, 71(10), 23502363.

Chernyak-Hai, L., \& Tziner, A. (2015). The I believe and the I invest of work-family balance: The indirect influences of personal values and work engagement via perceived organizational climate and workplace burnout. Revista De Psicología Del Trabajo Y De Las Organizaciones, $32(1), 1-10$.

Cheung, M., \& Wong, C. (2013). Work-family/family-work conflict: The moderating roles of gender and spousal working status. Asia Pacific Journal of Human Resources, 51, 330-346.

Coenen, M., \& Kok, R. W. (2014). Workplace flexibility and new product development performance: The role of telework and flexible work schedules. European Management Journal, 32, 564-576.

De Janasz, S., Behson, S. J., Jonsen, K., \& Lankau, M. J. (2013). Dual sources of support for dual roles: How mentoring and work-family culture influence work-family conflict and job attitudes. International Journal of Human Resource Management, 24, 1435-1453.

De Sivatte, I., \& Guadamillas, F. (2013). Antecedents and outcomes of implementing flexibility policies in organizations. International Journal of Human Resource Management, 24, 1327-1345. 
DiRenzo, M. S., Greenhaus, J. H., \& Weer, C. H. (2011). Job level, demands, and resources as antecedents of work-family conflict. Journal of Vocational Behavior, 78(2), 305-314.

Duncan, K. A., \& Pettigrew, R. N. (2012). The effect of work arrangements on perception of work-family balance. Community, Work \& Family, $15,403-423$.

Field, A. (2013). Discovering statistics using IBM SPSS statistics. CA: Sage Publications, Inc.

Fiksenbaum, L. M. (2013). Supportive work-family environments: Implications for work-family conflict and well-being. The International Journal of Human Resource Management, 25, 653-672.

Galea, C., Houkes, I., \& De Rijk, A. (2014). An insider's point of view: How a system of flexible working hours helps employees to strike a proper balance between work and personal life. International Journal of Human Resource Management, 25, 1090-1111.

Galinsky, E., \& Matos, K. (2011). The future of work-life fit. Organizational Dynamics, 40, 267-280.

Goh, Z., Ilies, R., \& Wilson, K. S. (2015). Supportive supervisors improve employees' daily lives: The role supervisors play in the impact of daily workload on life satisfaction via work-family conflict. Journal of Vocational Behavior, 89, 65-73.

Goode, W. J. (1960). A theory of role strain. American Sociological Review, $25,483-496$.

Gözükara, İ., \& Çolakoğlu, N. (2015). The impact of manager support and work-family conflict on job satisfaction. Business Management Dynamics, 5(6), 13-25.

Grandey, A. A., Cordeiro, B. L., \& Crouter, A. C. (2005). A longitudinal and multi-source test of the work-family conflict and job satisfaction relationship. Journal of Occupational \& Organizational Psychology, 78(3), 305-323. 
Greene, W. H. (2012). Econometric analysis ( $7^{\text {th }}$ ed.). Upper Saddle River, NJ: Prentice-Hall.

Greenhaus, J. H., \& Beutell, N. J. (1985). Sources and conflict between work and family roles. The Academy of Management Review, 10(1), 76-88.

Greenhaus, J. H., \& Powell, G. N. (2006). When work and family are allies: A theory of work-family enrichment. Academy of Management Review, 31(1), 72-92.

Harris, K. J., Harris, R. B., Carlson, J. R., \& Carlson, D. S. (2015). Resource loss from technology overload and its impact on work-family conflict: Can leaders help? Computers in Human Behavior, 50, 411-417.

Henly, J. R., \& Lambert, S. J. (2014). Unpredictable work timing in retail jobs: Implications for employee work-life conflict. Industrial and Labor Relations Review, 67, 986-1016.

Jerome, A., Scales, M., Whithem, C., \& Quain, B. (2014). Millennials in the workforce: Gen Y workplace strategies for the next century. E-Journal of Social \& Behavioural Research in Business, 5(1), 1-12.

Katz, D., \& Kahn, R. (1978). The social psychology of organizations. New York, NY: Wiley.

King, J. L. (2005), Research review: Work-family/family-work conflict. International Journal of Leadership Studies, 1(1), 102-105.

Kirchmeyer, C., \& Bullin, C. (1997). Gender roles in a traditionally female occupation: A study of emergency, operating, intensive care, and psychiatric nurses. Journal of Vocational Behavior, 50, 78-95.

Kossek, E. E., \& Ozeki, C. (1998). Work-family conflict, policies, and the job-life satisfaction relationship: A review and directions for organizational behavior-human resources research. Journal of Applied Psychology, 83(2), 139-149.

Lazarus, R. S. (1991). Progress on a cognitive-motivational-relational theory of emotion. American Psychologist, 46, 819-834. 
Li, D., Li, X., Wang, L., Wang, G., \& Newton, C. (2019). Work-family conflict influences the relationship between family embeddedness and turnover intention. Social Behavior and Personality: An International Journal, 47(4), e7640.

Locke, E. A. (1976). The nature and causes of job satisfaction. Chicago: Rand McNally

Maharshi, N., \& Chaturvedi, R. (2015). A study of factors-affecting the work-life balance of women employees working in public and private sector banks of Rajastan. Asia Pacific Journal of Management and Entrepreneurship Research, 4, 89-107.

Matthews, R. A., Kath, L. M., \& Barnes-Farrell, J. L. (2010). A short, valid, predictive measure of work-family conflict: Item selection and scale validation. Journal of Occupational Health Psychology, 15(1), 75-90.

Minnotte, K. L. (2012). Family structure, gender, and the work-family interface: Work-to-family conflict among single and partnered parents. Journal of Family and Economic Issues, 33(1), 95-107.

Moazami-Goodarzi, A., Nurmi, J.-E., Mauno, S., Aunola, K., \& Rantanen, J. (2019). Longitudinal latent profiles of work-family balance: Examination of antecedents and outcomes. International Journal of Stress Management, 26(1), 65-77.

Mortimer, J. T., Lorence, J., \& Kumka, D. S. (1986). Work, family, and personality: Transition to adulthood. Norwood: Ablex Publishing.

Munsch, C., Ridgeway, C., \& Williams, J. (2014). Pluralistic ignorance and the flexibility bias: Understanding and mitigating flextime and flexplace bias at work. Work and Occupations, 41(1), 40-62.

Neal, M. B., \& Hammer, L. B. (2007). Working couples caring for children and aging parents. Mahwah, NJ: Lawrence Erlbaum Associates.

Netemeyer, R. G., Boles, J. S., \& McMurrian, R. (1996). Development and validation of work-family conflict and family-work conflict scales. Journal of Applied Psychology, 81, 400-410. 
Odle-Dusseau, H. N., Hammer, L. B., Crain, T. L., \& Bodner, T. E. (2016). The influence of family-supportive supervisor training on employee job performance and attitudes: An organizational work-family intervention. Journal of Occupational Health Psychology, 21(3), 296-308.

Pandu, A. (2019). Predictors and outcomes of work-life balance among it employees and school teachers in Chennai: A SEM model approach. Journal of Strategic Human Resource Management, 8(1), 61-71.

Parker, K. \& Wang, W. (2013). Modern parenthood: Roles of moms and dads converge as they balance work and family. Retrieved from http://www.pewsocialtrends.org/files/2013/03/FINAL_modern_ parenthood_03-2013.pdf

Pavalko, E. K., \& Henderson, K. A. (2006). Combining care work and paid work: Do workplace policies make a difference? Research on Aging, $28,359-374$.

Poposki, E. M. (2011). The blame game: Exploring the nature and correlates of attributions following work-family conflict. Group \& Organization Management, 36(4), 499-525.

Raza, B., Ali, M., Naseem, K., Moeed, A., Jamil, A., \& Hamid, M. (2018). Impact of trait mindfulness on job satisfaction and turnover intentions: Mediating role of work-family balance and moderating role of workfamily conflict. Cogent Business \& Management, 5(1), 1542943.

Rhee, M. K., Park, S. K., \& Lee, C. K., (2019). Pathways from workplace flexibility to turnover intention: Role of work-family conflict, familywork conflict, and job satisfaction. International Journal of Social Welfare, 29(1), 51-61.

Shannon-Missal, L. (2014). Vast majority of Americans favor flexible workplace policies. Retrieved from Nielsen \& The Harris: http:// www.harrisinteractive.com/vault/Harris\%20Poll\%2059\%20-\%20 Working\%20Families_06.19.2014.pdf 
Society for Human Resource Management, (2013). Workplace flexibility in the 21st century: Meeting the needs of the changing workforce. Retrieved from http://secure-us.imrworldwide.com/cgi-bin/b?ci=usshrm\&cg=pdftracking\&tu=http://www.shrm.org/Research/ SurveyFindings/Articles/Documents/09-0464_Workplace_Flexibility_ Survey_Report_inside_FINALonline.pdf

Society for Human Resource Management, (2016). 2016 Strategic BenefitsFlexible Work Arrangements. Retrieved from https:/www.shrm.org/ hr-today/trends-and-forecasting/research-and-surveys/pages/2016strategic-benefits $\% \mathrm{E} 2 \% 80 \% 95$ flexible-work-arrangements-(fwas).aspx

Somech, A., \& Drach-Zahavy, A. (2012). Coping with work-family conflict: The reciprocal and additive contributions of personal coping and organizational family-friendly support. Work \& Stress, 26, 68-90.

Sturman, M. C., \& Walsh, K. (2014). Strengthening the employment relationship: The effects of work-hours fit on key employee attitudes. Journal of Organizational Behavior, 35(6), 762-784.

Swanberg, J. E., McKechnie, S. P., Ojha, M. U., \& James, J. B. (2011). Schedule control, supervisor support, and work engagement: A winning combination for workers in hourly jobs? Journal of Vocational Behavior, 79, 613-624.

Sweet, S., Pitt-Catsouphes, M., Besen, E., \& Golden, L. (2014). Explaining organizational variation in flexible work arrangements: Why the pattern and scale of availability matter. Community, Work \& Family, 17, 115141.

Thompson, C. A., Beauvais, L. L., \& Lyness, K. S. (1999). When workfamily benefits are not enough: The influence of work-family culture on benefit utilization, organizational attachment, and work-family conflict. Journal of Vocational Behavior, 54, 392-415.

Tripathi, P., \& Pandey, M. K. (2017). Examining the relationship between work-family conflict, job satisfaction, and employee turnover intention. Journal of Psychosocial Research, 12(2), 451-459. 
Wahyuni, D. (2012). The research design maze: Understanding paradigms, cases, methods, and methodologies. Journal of Applied Management Accounting Research, 10(1), 69-80.

Weiner, B. (1974). Achievement motivation and attribution theory. Morristown, NJ: General Learning Press.

Weiner, B., Frieze, I., Kukla, A., Reed, L., Rest, S., \& Rosenbaum, R. M. (1971). Perceiving the causes of success and failure. In E. E. Jones. (Eds.), Attribution: Perceiving the causes of behavior (pp. 95-120). Hillsdale, NJ: Lawrence Erlbaum.

Wells-Lepley, M., Thelen, L. A., \& Swanberg, J. (2015). Supervisors' use of flexibility as a strategic management tool: Prevalence and predictors. The Psychologist-Manager Journal, 18(1), 31-53.

World Bank, (n.d). Section 9: Growth of the service sector. Retrieved from http://www.worldbank.org/depweb/beyond/beyondco/beg_09.pdf

Yang, J., Mossholder, K. W., \& Peng, T. (2009). Supervisory procedural justice effects: The mediating roles of cognitive and affective trust. The Leadership Quarterly, 20, 143-154.

Zhang, M., Fried, D. D., \& Griffeth, R. W. (2012). A review of job embeddedness: Conceptual, measurement issues, and directions for future research. Human Resource Management Review, 22(3), 220-231.

Zito, M., Colombo, L., Borgogni, L., Callea, A., Cenciotti, R., Ingusci, E., \& Cortese, C. G. (2019). The nature of job crafting: Positive and negative relations with job satisfaction and work-family conflict. International Journal of Environmental Research and Public Health, 16(7), 1176. 